\title{
A Systematic Review of Higher Education Academics' Use of Microblogging for Professional Development: Case of Twitter
}

https://doi.org/10.1515/edu-2020-0102

received March 10, 2020; accepted April 11, 2020.

\begin{abstract}
The paper presents a systematic literature review of empirical studies on the use of Twitter by higher education academics for professional development. Using content and thematic analyses, this review addressed four research questions related to study characteristics, theoretical and methodological approaches, and the type of professional development activities engaged. The results show that Twitter has been studied from several perspectives using various methodological approaches. The review revealed several limitations, including the paucity of research addressing gender, cultural and geographic differences. Limited use of theory is also observed. Five themes emerged identifying the ways Twitter was used for professional development: 1) academic backchannel, 2) networking, 3) information and resource sharing, 4) keeping updated, 5) public engagement and social commentary. Overall, the literature review suggests Twitter supports some aspects of professional development. However, several issues remain outstanding and in need of further research, including ethical approaches and practices of researchers related to data collection and use.
\end{abstract}

Keywords: Twitter; Professional Development; Academics; Social Networks; Literature Review.

\section{Introduction}

Higher education institutions and their academics face newer challenges and opportunities in the current academic climate (Austin \& Sorcinelli, 2013) because of the multifaceted nature of higher education (Frick

\footnotetext{
*Corresponding author: Lenandlar Singh, Department of Computer Science, University of Guyana, E-mail: lenandlar.singh@uog.edu.gy
}

\& Kapp, 2009). One way to address these challenges is through professional development of academics. Academic development is a key strategic lever for ensuring institutional quality and supporting institutional change in higher education and is central to the development of the academic staff (Frick \& Kapp, 2009; Beach, Sorcinelli, Austin \& Rivard, 2016; Bali \& Caines, 2018)

Professional development, sometimes referred to as academic professional development (APD) (Frick \& Kapp, 2009), faculty development, academic development, educator/educational development (Bali \& Caines, 2018) or professional learning (Oddone, 2019) is concerned with developmental activities aimed at improving practice (Cervero, 2000). These practices include updating skills and knowledge, preparation for new roles in organisations, and general competence development in the wider academic context (Challis, 1999), and collaboration (Shagrir, 2017). Similarly, Zou (2018) identified knowledge sharing and development, help-seeking, problem-solving, mentoring, modelling, sharing good principles and practices, and continuous skills development as critical to the development and transformation of learning and teaching. Though professional development is important for career satisfaction (Heffernan \& Heffernan, 2019), it is often not adequately provided (Summers, 2017) or provided effectively (Odalen, Brommesson, Erlingsson \& Fogelgren, 2018).

To address the inadequacy of opportunities within their own institutions and to explore more progressive approaches to professional development, academics have turned to the Internet as an alternative support system for career development. The Internet affords the formation of learning networks and has the potential to facilitate emergence and self-organised learning (Williams, Karousou \& Mackness, 2011). In this way the Internet is described as an extended learning environment and a powerful source for the development of learning ecologies (Looi, 2008). Online social networks are a critical part of online learning ecologies as they extend offline spaces; 
allow for connections beyond the local environment; facilitate social interactions and self-development and self-organisation, which in turn enables collaboration, cooperation, negotiation, and creation and sharing, all of which are central to the professional development of academics in the modern higher education space (Bozkurt et al., 2016; Bozkurt \& Hilbelink, 2019).

This literature review examines how Twitter, a specific social network and part of the growing online learning ecology, has been used to support the professional development of higher education academics.

\subsection{Literature Review}

\subsubsection{Social Networks and Twitter}

Social networks are used to create and sustain social connections according to boyd and Ellison (2007). While they are created for social purposes, they are repurposed for professional usage (Meishar-Tal \& Pieterse, 2017). In higher education social networks have been adopted and incorporated into many aspects of University operations (Lupton, 2014) and are influencing the work routines of academics (Donelan, 2016) and professional practice (Conole \& Alevizou, 2010; Moran, Seaman \& Tinti-Kane, 2011; Veletsianos \& Kimmons, 2013).

Advocates of social networks have argued for their use in professional development. Krutka and Carpenter (2016) suggested that through Professional Learning Networks (PLNs) it is possible to mediate the professional engagements of academics by allowing for connections among many people, in different spaces, using a variety of tools. Meishar-Tal and Pieterse (2017) found that PLNs facilitate knowledge development, interaction and networking among peers. Trust, Carpenter and Krutka (2017) highlighted that their persistent availability and expansiveness fostered new learning experiences. Others have argued that PLNs have the potential to bridge the boundaries between formal and informal learning (Greenhow \& Lewin, 2016), change the nature of scholarly practice (Chapman \& Greenhow, 2019; Greenhow, Gleason \& Staudt Willet, 2019) and scholarly communication (Sugimoto, Work, Larivière \& Haustein, 2017) facilitate communication with others and to allow the finding and sharing of information (Mansour, 2015; Manca \& Ranieri, 2016).

Twitter is a microblogging social network that allows users to communicate using short text messages of 140 characters (Tang \& Hew, 2017) previously, and presently 280 characters (Emke, 2019). Literature reviews synthesising Twitter's use in higher education exist, but they have not specifically addressed professional development. For example, Gao, Luo and Zhang (2012) critically analysed 21 articles published between 2008 and 2011 focusing on several areas, including the use of Twitter for teaching and learning. Similarly, Tang and Hew (2017) analysed 51 published between 2006 and 2015 on students' use of Twitter in teaching and learning. Further, Tang and Hew (2017) identified several literature reviews that synthesised findings of Twitter in teaching and learning. Tang and Hew (2017) suggested sociocultural differences in use and educators' perspectives are outstanding issues to be addressed. They also emphasised the need for more longitudinal studies. Gao, Luo and Zhang (2012) and Xing and Gao (2018) also suggested the need for more longitudinal studies, while Trust, Carpenter and Krutka (2017) noted the absence of comparative research across country and culture. Veletsianos and Shaw (2018) highlighted the need for more studies exploring gender-based participation and the need for data collected over longer periods of time. Veletsianos (2016) suggested scholars' use of social media is not well understood and is still fragmented. Specific to Twitter, despite its increasing levels of adoption among educators (Lupton, 2014; Staudt Willet, 2019; Veletsianos, 2017; Xing \& Gao, 2018), not much is known about its use by scholars (Mahrt, Weller \& Peters, 2015) and the factors that affect its use in professional development activities (Gao \& $\mathrm{Li}$, 2019).

\subsubsection{Use of Theory}

The use of theory in technology enhanced learning has come under scrutiny recently. In an extensive literature review of educational technology studies, Hew, Lan, Tang, Jia and Lo (2019) asked the question "where is the theory?". They reported that in a majority of cases explicit engagement with theory was absent and where used, it was mainly to conceptualize research and not to advance theory development. Previously it was suggested that the field of educational technology is mainly concerned with practical implementation (Bennett \& Oliver, 2011) and that there is a failure of research within the field to explain technology theoretically (Oliver, 2013). Thus, the field is described as being under-theorised (Jones \& Czerniewicz, 2011; Markauskaite \& Reimann, 2014). In this study the extent of theory use is explored. 


\subsubsection{Ethical Considerations}

Social media has become a popular source of data for researchers mainly due to the ease with which data can be harvested using new tools and APIs (Pfeffer, Mayer \& Morstatter, 2018); the sheer volume of data available (Ahmed, 2017; Murphy, 2017); and the richness of cultural and social data (Stewart, 2017). However, the matter pertaining to how to address the ethical issues related to data collection from social media in general and Twitter in particular is not yet settled (Kelley, Cranshaw \& Sleeper, 2013). Ethical questions related to users' data remains open and issues related to privacy are yet to be fully addressed (Zwitter, 2014). However, addressing ethical issues may challenge researchers as it may not be possible to contact users of large datasets to obtain informed consent (Ahmed, Bath \& Demartini, 2017). In addition, Twitter's terms of service and use agreements may allow third parties to collect and use participants' data (Ahmed, Bath \& Demartini, 2017). However, Twitter users may not be aware of the way researchers can use their data and express the concern that researchers should not use their data without informed consent (Fiesler \& Proferes, 2018). In many instances, researchers themselves do not pay attention to the requirement of ethics or treat data from Twitter as part of the public domain (Costello, Donlon \& Brown, 2019). This apparent indifference creates a dilemma for researchers, ethics boards and IRBs, and users. This study continues the conversation on social media research ethics by drawing attention to ethical choices made by researchers.

\subsection{Aim and Context of the Study}

This systematic literature review examines the use of Twitter by higher education academics for professional development purposes. To the best of my knowledge, no known literature review focused exclusively on how higher education academics used Twitter for professional development activities.

This review is significant in two ways. It will help educational practitioners and academics understand how Twitter may support professional development. It provides a summary and critique of the existing body of research on the use of Twitter for professional development. It also offers guidance for future research by highlighting outstanding methodological, theoretical and ethical questions and issues.

This study is guided by one overarching research question - What is the status of research on higher education academics use of Twitter for professional development? Four specific questions are addressed:

RQ1. What are the characteristics of publications on the use of Twitter for professional development in higher education in terms of study purpose, country, academic discipline, gender, and sample size?

RQ2. What are the theoretical and methodological approaches used?

RQ3. How is Twitter used by academics?

RQ4. How is ethics addressed when Twitter is used as a research tool and data source?

\section{Methodology}

\subsection{Searching and Selection Procedure}

The papers reviewed used in this systematic literature review were identified using two main sources: the Scopus database, and seven selected journals renowned for publishing papers similar to those needed for this study; Computers and Education, British Journal of Educational Technology, Internet and Higher Education, Australasian Journal of Educational Technology, Journal of Educational Technology and Society, Journal of Computing in Higher Education, The International Review of Research in Open and Distributed Learning. To supplement these two sources, a snowball search for additional relevant articles referenced in already identified articles was conducted. An exhaustive Google Scholar search was also conducted.

The first search phase took place on July 14, 2019. The following searched terms were used - "Twitter in higher education", "higher education academics", "professional development", "professional learning". Scopus returned 487 articles for "Twitter in Higher education". This search was refined using the "AND" operator. A total of returned 113 articles was returned for "Twitter in higher education AND higher education academics" AND professional development", of which 12 were selected. 101 articles were excluded after they were reviewed against the following inclusion criteria i) context of higher education ii) Use of Twitter for professional development by academics iii) empirical studies and iv) articles peer reviewed. A further refinement of the search string to "Twitterin highereducation AND higher education academics AND professional learning" returned another 33 articles of which 5 were selected (28 excluded). The final decision on the 17 articles from SCOPUS was done by scanning their titles and by reading through their abstracts to ascertain relevance. The 
articles excluded (129) were those where Twitter was used outside of higher education or within higher education but not in the context of professional development. Opinions and theoretical articles were also excluded.

On July 15, 2019 Google Scholar was searched exhaustively using similar inclusion/exclusion criteria and search terms, yielding an additional 3 articles. On July 16, 2019, the seven selected Journals were searched by examining article titles in each volume and issue. 4 articles were identified from this process. Several articles from the journals were already found on SCOPUS. Finally, the snowball search identified 4 articles. Table 1 presents a summary.

\subsection{Data Extraction and Analysis Procedure}

The 28 papers were read and analysed individually and relevant information extracted and short codes and phrases were recorded in two spreadsheets (Appendix A, Appendix B). Data on the purpose of study (Table 3), academic discipline country of study, gender and sample size (Appendix B) were extracted to answer RQ1. Appendix B contains extracted data on theoretical and methodological approaches and is used to answer RQ2. Thematic analysis was used to address RQ3. Thematic analysis was used to derive themes from extracted data and followed the sixphase approach proposed by Braun and Clarke (2006). These phases are: i) familiarizing yourself with your data, ii) generating initial codes, iii) searching for themes, iv) reviewing themes, v) defining and naming themes, and vi) producing the report (Braun \& Clarke, 2006, p. 78). Content analysis of the methodology and ethics section of each paper reviewed was used to address RQ4 (ethics).

\section{Results}

Table 2 provides a summary of the papers reviewed.

\subsection{Research Question 1 (RQ1) - What are the characteristics of publications...?}

\subsubsection{Purpose of Study}

Through analysis of each paper 10 purposes were identified. Table 3 shows these studies and the purposes identified.

The most popular type of study focused on Twitter's use in academic conferences $(n=10)$. How individuals
Table 1: Sources of papers.

\begin{tabular}{ll}
\hline Search Source & \# articles included \\
\hline SCOPUS & 17 \\
Selected Journals & 4 \\
Google Scholar & 3 \\
Snowball approach & 4 \\
Total & $\mathbf{2 8}$ \\
\hline
\end{tabular}

Table 2: Papers reviewed.

\begin{tabular}{|c|c|}
\hline ID & Authors \\
\hline A1 & (Reinhardt, Ebner, Beham \& Costa, 2009) \\
\hline A2 & (Ross, Terras, Warwick \& Welch, 2011) \\
\hline A3 & (Veletsianos, 2012) \\
\hline A4 & (Shiffman, 2012) \\
\hline A5 & (Lewis \& Rush 2013) \\
\hline A6 & (Holmberg \& Thelwall, 2014) \\
\hline A7 & (Wen, Lin, Trattner \& Parra, 2014) \\
\hline A8 & (Quan-Haase, Martin \& McCay-Peet, 2015) \\
\hline A9 & (Li \& Greenhow, 2015) \\
\hline A10 & (Ferguson \& Wheat, 2015) \\
\hline A11 & (Ross, Maninger, LaPrairie \& Sullivan, 2015) \\
\hline A12 & (Stewart, 2015) \\
\hline A13 & (McPherson, Budge \& Lemon,2015) \\
\hline A14 & (Kimmons \& Veletsianos, 2016) \\
\hline A15 & (Budge, Lemon \& McPherson, 2016) \\
\hline A16 & (Knight \& Kaye, 2016) \\
\hline A17 & (O’Keeffe, 2016) \\
\hline A18 & (Veletsianos \& Kimmons, 2016) \\
\hline A19 & (Parra et al. ,2016) \\
\hline A20 & (Ramirez \& Garcia, 2017) \\
\hline A21 & (Shah \& Cox, 2017) \\
\hline A22 & (O’Keeffe, 2018) \\
\hline A23 & (Shah \& Cox, 2018) \\
\hline A24 & (Veletsianos, Kimmons, Belikov \& Johnson, 2018) \\
\hline A25 & (Mohammadi, Thelwall, Kwasny \& Holmes, 2018) \\
\hline A26 & (Albertson, 2019) \\
\hline A27 & (Fekete \& Haffner, 2019) \\
\hline A28 & (Greenhow, Lai \& Mai, 2019) \\
\hline
\end{tabular}


Table 3: Purpose of studies.

\begin{tabular}{|c|c|c|c|}
\hline Index & Research Purpose & Papers & \# of studies \\
\hline 1 & Explain Twitter's Use at Conferences & $A 1, A 2, A 4, A 7, A 9, A 14, A 19, A 26, A 27, A 28$ & 10 \\
\hline 2 & $\begin{array}{l}\text { Study of professional use in daily activities (in situ) and } \\
\text { temporal participation }\end{array}$ & $A 3, A 16, A 18, A 20, A 21, A 22, A 23, A 24$ & 7 \\
\hline 3 & $\begin{array}{l}\text { Explore How Twitter is used for Professional/ Informal } \\
\text { learning }\end{array}$ & $A 11, A 13, A 17$ & 3 \\
\hline 4 & $\begin{array}{l}\text { Explore how Twitter helped develop Community of } \\
\text { Practice }\end{array}$ & A5 & 1 \\
\hline 5 & Identify disciplinary differences in Use of Twitter & A6 & 1 \\
\hline 6 & Explore Use and Gratification & A8 & 1 \\
\hline 7 & Explore Twitter as a Tool for mentoring & A10 & 1 \\
\hline 8 & Describe the use of Twitter in Scholarly practice & A12 & 1 \\
\hline 9 & Explore how Twitter facilitates identity formation & A15 & 1 \\
\hline 10 & Examine type of academic information on Twitter & $\mathrm{A} 25$ & 1 \\
\hline
\end{tabular}

engage Twitter professionally in the course of their daily life was second most popular ( $\mathrm{n}=7)$, followed by Twitter's use for professional and informal learning $(n=3)$.

\subsubsection{Subject disciplines, country of study, gender and sample size}

Of the 28 studies reviewed, 17 did not explicitly state the country of origin of participants. Of the remaining 11 studies, 5 originated from the UK and 4 from the USA, while 2 of the studies comprised participants from Canada and Australia. Two of the studies comprise participants from the non-English speaking world (A12, A20).

In terms of discipline, 9 of the 28 studies did not explicitly identify a domain. Where stated, Education and Humanities was the most commonly occurring discipline (11), followed by Computer and Information Sciences (3), Social Sciences (2), Arts (2) Medicine (1), Geography (1), Biology (1).

Data for the studies reviewed came from two sources - human subjects through interviews, narratives, online surveys, and Twitter activities. Where Twitter data was collected, data collection periods varied. 13 studies did not explicitly state the duration of data collection. Where stated duration ranged from 2 weeks to several months. Several studies collected data over several years (A7, A19, A28). Data for the single observation study (A12) was collected over a period of 4 months.

Sample sizes varied -2 of the 3 (A1, A16) online surveys had fewer than 50 participants while 1 had over 1900 (A25). One observation study (A12) had 14 participants. There were two narrative studies (A13, A15) with 3 researchers/participants. Where Twitter activities were used, the number of tweets varied with 1 study (A24) using more than 9 million tweets, while another (A4) just over 1,700 tweets.

In terms of gender, 6 of the 28 studies (A1, A3, A8, A11, A12, A24) provided information but only one - Stewart (2015) [A12] attempted an analysis by gender. This study, however, was small (10 females) and the analysis brief. Veletsianos, Kimmons, Belikov and Johnson (2018) [A24] predicated gender by screen names but did no further gender analysis.

\subsection{Research Question 2 (RQ2) - What are the theoretical and methodological approaches used?}

\subsubsection{Methodology and Methods}

The 28 papers reviewed demonstrated the use of different research methodologies. Table 4 shows these methodologies.

In particular, several different data collection methods were noted as shown in Table 5.

Tweeting, retweeting, and other similar activities were the most popular data sources $(n=15)$ followed by interviews ( $\mathrm{n}=7$ ) and online surveys (3). In contrast, only a single study used direct observation. 
Table 4: Methodologies used.

\begin{tabular}{ll}
\hline Methods & \# of studies \\
\hline Quantitative & 12 \\
Qualitative & 10 \\
Mixed Methods & 6 \\
\hline
\end{tabular}

Table 5: Source of data.

\begin{tabular}{ll}
\hline Data Collection Method & \# of studies \\
\hline Twitter data & 15 \\
Interviews & 7 \\
Online surveys & 3 \\
Narratives & 2 \\
Observation & 1 \\
\hline
\end{tabular}

Table 6: Theoretical frameworks used.

\begin{tabular}{lll}
\hline Theoretical Framework & Paper(s) & \# of studies \\
\hline Community of Practice & A5, A9, A28 & 3 \\
Use and Gratification & A8 & 1 \\
Social Learning & A9 & 1 \\
$\begin{array}{l}\text { Connectivism } \\
\text { Boyer's 1990 4 component of }\end{array}$ & A9, A11 & 2 \\
$\begin{array}{l}\text { scholarship } \\
\text { Networked Participatory }\end{array}$ & A14, A18 & 2 \\
$\begin{array}{l}\text { Scholarship } \\
\text { Digital Identities and Digital }\end{array}$ & A15 & 1 \\
Literacies & & 1 \\
Digital Scholarship & A15 & 1 \\
Visitor and Resident Topology & A17 & 1 \\
Castells' Communication Networks & A20 & 1 \\
Baron's Learning Ecology & A28 & 1 \\
\hline
\end{tabular}

\subsubsection{Theoretical Frameworks}

Theoretical frameworks were not used in 17 of the 28 studies. Where used, 11 different frameworks were identified. Table 6 shows the 11 papers that used a theoretical framework.

Community of Practice was the most popular theory used (3) following by Connectivism (2) and Networked Participatory Scholarship (2).

\subsection{Research Question 3 (RQ3) - How is Twitter used?}

Five categories of use emerged from the thematic analysis. These are 1) Academic backchannel, 2) Networking, 3) Information and Resource Sharing, 4) Keeping Updated, 5) Public Engagement and Social Commentary.

\subsubsection{Academic Back Channel (ABC)}

The most salient and visible theme emerging from the data analysis points to Twitter's use as a backchannel for academic activities of which the conference is the most prominent. Specifically, 10 of the 28 articles (see Table 3 above) reviewed explored how Twitter is used for conference activities. In particular, several activities characterise the conference backchannels experiences. These include: 1) sharing information and resources (A1, A7, A9, A28); 2) communicating with others (A1, A2, A7, A19, A27, A28); 3) knowledge enhancement (A1, A2, A9, A27); 4) networking and connecting with others (A1, A2, A7, A9, A27); 5) keeping updated and knowledge enhancement (A2); 6) social commentary and reporting (A2, A4, A28); 7) identity and impression management (A1); 8) develop digital literacy (A8).

It is important to highlight that several of the activities associated with the academic backchannel are also reported in other studies reviewed, as described in the following sections.

\subsubsection{Networking}

Networking and connecting with others were a prominent theme across several other papers than those reporting on the academic backchannel. These include (A3, A5, A9, A11, A13, A15, A16, A25). Specifically, several participants reported creating PLNs (A5, A11) and networks of practice (A5). There was one instance of a global network (A13).

\subsubsection{Information and Resource Sharing}

Information and resource sharing and propagation featured prominently among many of the papers reviewed. Similar to the conference backchannel studies, several papers reported on other information sharing practices (A3, A4, A6, A7, A9, A10, A12, A16, A18, A19, A20, A21, A25). Various types of information and resources were shared, including for example tips and tricks (A17); links to other 
resources such as websites, blogs, social media sites, (A6, A20); research results (A25).

\subsubsection{Keeping updated}

Several studies reported that participants were also actively seeking information from their Twitter network to keep up to date with developments in their fields and interests (A8, A16, A17, A21, A22, A25)

\subsubsection{Public Engagement and Social Commentary}

A majority of the studies reviewed point to the way Twitter is used as a space for public and social engagements. The engagement in social commentary was highlighted as an important use of the backchannel at conferences (A3). Further, several activities highlighted the public and social use of Twitter, including: promoting events, articles, interviews and radio shows (A6); invitations to participate and contribute to knowledge (A12); raising of conversations on issues of interest (A12, A25); organising events (A16); invitation to write journal articles, present at conferences, and write blogposts, (A17); and the promotion of scholarship (A28).

\subsection{Research Question 4 (RQ4) - How is ethics addressed when Twitter is used as a research tool and data source?}

Of the 28 papers reviewed, only 6 (A10, A14, A16, A17, A25, A28) addressed ethical approval for data collection, usage, and participant consent and engagement. 22 of the 28 papers did not provide information or made references to ethics. Of the 6 papers, 4 received institutional ethics board approval (A10, A14, A17, A25), 1 received departmental approval (A16), and the other just noted research ethics were followed. 2 of the studies (A10, A28) noted data publicly available. 3 of the 6 papers noted data was anonymised and pseudonyms used to protect participants (A14, A17, A28). Participants were contacted for explicit approval in 3 of the 6 studies (A10, A17, A28).

\section{Discussion}

The purpose of this paper is to present a review of published empirical studies on the use of Twitter by higher education academics in the context of professional development. The review suggests that Twitter has been studied across several disciplines using various methodological and theoretical approaches and that academics have used Twitter in several ways to support professional development. These are discussed below:

\subsection{Purpose of Studies}

Ten different purposes for which Twitter is studied in the context of professional development in higher education were inferred from the literature review. This is an indication that a range of interests exists among researchers.

Twitter as a conference support tool and backchannel accounted for the highest proportion of studies $(n=10)$. This is an encouraging finding for several reasons. Attending academic conferences is an important element of professional development and networking (Spilker, Prinsen \& Kalz, 2019) and Twitter extends the reach of conferences making them more accessible to those who may not be able to attend in person (Bombaci et al., 2015). Therefore, an understanding of how Twitter is used in conferences could help with making better decisions about participation and engagement. However, we are cautioned that we do not yet know enough about how social media are used to support professional development and community building (Spilker, Prinsen \& Kalz, 2019). The second most studied area is how Twitter is used by academics in everyday settings $(n=7)$, indicating that some attention has been dedicated to understanding how Twitter is by individuals.

While there is a greater attempt to collect data over a longer duration of time or across multiple time periods, most of the studies use data collected over a short period of time. To this end, the need for more longitudinal data to better understand has been expressed by several researchers (Gao, Luo \& Zhang, 2012; Tang \& Hew, 2017; Xing \& Gao, 2018). Also, sample sizes varied, making it difficult to compare results across studies.

Approximately $60 \%(n=17)$ of the papers did not provide country level data and those that did, were mainly from USA or UK participants. This suggests our knowledge of Twitter thus far might be skewed towards the developed, English-speaking environment. Further, the cultural and geographic context of Twitter's use among academics may exist, given that differences in use among different social media platforms exist (Sugimoto, Work, Larivière \& Haustein, 2017). Consequently, there has been a call 
for a more contextual understanding of Twitter's use in academia by Tang and Hew (2017).

Gender-based analyses did not feature prominently in the studies reviewed. Approximately $80 \%(n=22)$ of the studies did not mention gender. Strikingly, only a single study collected and analysed data related to gender (Stewart, 2015). This study reported that Twitter provided a space for underrepresented women to participate. However, among teachers using Twitter, there is emerging evidence of gender differences in participation (Kerr \& Schmeichel, 2018). Therefore, attention to gender differences is critical especially in light of issues related to scholarly communication (Sugimoto, Work, Larivière \& Haustein, 2017) and career development paths and challenges experienced by women in higher education (Zacher, Rudolph, Todorovic \& Ammann, 2019).

\subsection{Theoretical and Methodological Approaches}

The studies reviewed used a range of qualitative, quantitative and mixed methods. There is an inclination towards using large scalequantitative data from Twitter and from online surveys. Quantitative tools are now commonly used in social network research (Ahmed, 2017) and may be influencing the methodological approaches used to study Twitter. Qualitative studies are in the minority and Lupton (2014), having noticed the proliferation of quantitative approaches in studying social media, suggests that future research should embrace more qualitative approaches with detailed descriptions. Similarly, Oddone (2019) suggests that personal qualitative approaches are likely to reveal experiences with personal learning networks that may not be possible with quantitative studies.

From a theoretical standpoint, there appears to be no preference for any particular theory given the range of the theories used. Theories were mainly used to conceptualize research and to inform data collection. In a minority of cases theory was used to explain results. No theory advancement was noticeable. These observations are consistent with those of Hew, Lan, Tang, Jia and Lo (2019) and Oliver (2013). Though the use of a range of theories could be considered positive in some respects, it could also be a function of the uncertainty on what theories are appropriate for the study of technology in education (Hannon \& Al-Mahmood, 2014). Czerniewicz (2008) suggested that this paucity of theory in educational technology research could be due to the unclear demarcation between the scholar and practitioner, where both scholar and practitioner may be the same person and therefore more emphases may be placed on the practical over the theoretical.

\subsection{Use of Twitter for Professional Development}

The thematic analysis revealed 5 major uses of Twitter by higher education academics in the context of professional development. These are: 1) Academic backchannel, 2) Networking, 3) Information and resource sharing, 4) Keeping updated, 5) Public engagement and social commentary.

Three of these themes [2,3,5] corresponds directly to those of Veletsianos (2012) even though that study was skewed by gender with 38 males and 7 females. Though the author highlighted this limitation, seven years later these three categories of use persist. In particular, as a space for networking Twitter allows higher education academics to connect across geography and culture while providing a range of knowledge to support continuous professional development. These findings are consistent with those reported by Pataraia, Margaryan, Falconer and Littlejohn (2013) and Jordan and Weller (2018a, 2018b) which highlighted how academics utilize their personal networks.

This study has shown that conference participation is a popular use of Twitter as a backchannel. As a backchannel Twitter provides a space for academics to engage in various scholarly and academic-related activities. The Twitter backchannel has demonstrated the potential to impact scholarly practice of academics (Chapman \& Greenhow, 2019; Greenhow, Gleason \& Staudt Willet, 2019) by extending the scholarly communication channel (Sugimoto, Work, Larivière \& Haustein, 2017) to a more diverse group of academics. However, Twitter as a conference backchannel is not without issues though open to everyone because in some instances small numbers of users may contribute proportionally more than others (Kimmons \& Veletsianos, 2016).

In a review of papers focusing on the use of Twitter for communicating academic work, Mahrt, Weller and Peters (2015) reported that Twitter is part of the ecology of scholarly communication outlet, but its use varies among different academic disciplines. This study confirms those findings as academics are using Twitter to share information, exchange ideas, and discuss topics of interest. Overall, this study has shown that Twitter is a useful tool for supporting the professional development of academics (Krutka \& Carpenter, 2016) by facilitating connections and networking (Trust, Carpenter and Krutka (2017) and informal learning (Greenhow \& Lewin, 2016). 


\subsection{Ethics}

This study found that approximately $80 \%$ of the papers reviewed did not address issues related to ethics and data collection. This finding is consistent with those reported by Costello, Donlon and Brown (2019). The requirements of ethical approval for the use of Twitter data for research remains inconsistent among researchers. The data suggests that researchers are more likely to not seek approval.

What factors might possibly explain the inconsistent approach taken by a majority of researchers not to address ethics when using Twitter data? The literature suggests that this inconsistency could possibly be due to misconceptions about the use of social media data (Costello, Donlon \& Brown, 2019) and the practical challenges associated with seeking informed consent from a large user base (Ahmed, Bath \& Demartini, 2017). Further, Hogue and Ennis-O'Connor (2017) draw attention to several dilemmas and challenges that could make it difficult for researchers to attend to ethical issues. However, they urge that these dilemmas and challenges are contextual and should not be ignored but attended to when decisions are made about the use of Twitter data for research. To address these challenges, Fiesler and Proferes (2018) suggested that newer methodological approaches that include the voices of the research community and the participants whose data is collected should be considered.

\section{Conclusions, Limitations, Impli- cations and Future Work}

Two limitations should be noted about this study. Firstly, this review focused on empirical studies written in the English language and may have therefore missed important papers that addressed this topic published in other languages. Secondly, these studies were taken from particular databases and journals. It is possible important studies were excluded because they fell outside of the search criteria employed in this study. Nevertheless, this study offers several insights on Twitter's potential for supporting professional development of higher education academics.

Professional development around the use of technology positively impacts academics by improving confidence (Flavell, Harris, Price, Logan \& Peterson, 2019) and can lead to significant personal growth (Teras, 2016). The results from this study have implications for practice, theory and further research. This study found that academics used Twitter to support professional development through networking, information sharing, help seeking, communication and public engagement, and to keep up to date with their interests. Collectively, these findings are consistent with the principles of networked learning (Dirckinck-Holmfeld, 2016; Hodgson \& McConnell), suggesting that Twitter provided a space for academics to connect and to collaborate for professional and scholarly development. The conference backchannel was found to be a popular means for scholarly activities but it remains a largely understudied aspect of Twitter's use for professional development activities among higher education academics. Further research could investigate the experiences of academics when Twitter is used as a conference backchannel by academics. Future studies could also explore the impact of networking on the upward mobility of academics and its impact on their social and emotional development.

From the standpoint of practice, two lessons can be learned from this literature review. Firstly, the review brings into focus several good practices for professional development which can be adopted by academics in an individual capacity. Further, the review highlights practices that can be adopted by institutions of higher education to guide their development of professional development activities. Institutions may also consider recognising and rewarding the use of Twitter for professional development activities given the time and effort expended and the positive outcomes experienced by their members.

Methodologically, a greater focus on quantitative methods was observed along with the limited use of theory. For researchers the study has identified the need for several areas to be further addressed: 1) more longitudinal studies, 2) gender-based participation, 3) cross cultural comparisons, 4) differences in use among diverse academic levels e.g. early career academics. In addition, future research could explore what Strydom and Fourie-Malberbe (2019) refer to as "methodological pluralism" with more emphases on the use of qualitative approaches such as phenomenography and ethnography and other observation-based methods to help better understand the experiences and impact of Twitter on the professional lives of academics.

From a theoretical standpoint, this literature review is consistent with the previously identified paucity of the use of theory to the study of technology in education (Hew, Lan, Tang, Jia \& Lo, 2019; Jones \& Czerniewicz, 2011; Markauskaite \& Reimann, 2014; Oliver, 2013). The question "where is the theory?" posed recently by Hew, Lan, Tang, Jia and Lo (2019) is echoed in this paper given that a minority of the studies reviewed made use of theory. 
So, what might be the implications of this deficiency in the use of theory? The sparse use of theory in technology studies affects the theoretical understanding of the technologies and their link to learning (Oliver, 2013). One implication of this sparsity is the slow theoretical consolidation of our understanding of technology which means that our understanding of the link between technology and its impact remains limited to the practical experiences gathered on a case by case basis and their affordances (Oliver, 2013). This has further implications for the transfer of knowledge across contexts which could be costly as understandings from one learning context may not apply across other contexts. Future work should place more emphasis on the use of theoretical lenses to serve both as a conceptual frame and for explaining results arising from such studies. In addition, future work could examine theories not yet explored in this context such as identity development, cognitive theories of learning given Twitter's use for supporting learning, and so on. Theories related to professional development could also be explored as they may shed light on aspects of professional development beyond traditional views that see the institution as the centre of professional development initiatives. The review also highlighted several under-researched areas, including gender and cultural differences, which could be the subject of further research.

Finally, the application of ethics to use of Twitter data remains inconsistent as this study shows and as previously reported (boyd \& Crawford, 2011; Kitchin, 2014). This finding has implications for researchers and those responsible for managing and approving research projects that use social media and in particular Twitter data. Regardless of the challenges in addressing ethical issues researchers must keep in mind the potential of harm to those whose data is being collected (Stewart, 2017). To this end, those managing and approving research projects could adopt existing policies guiding social media research or develop new policies to assist researchers in navigating the dilemmas and challenges of conducting social media research. Future research could address other domains of study to better understand the scope of this problem. And from an end-user standpoint, future research could explore users' perceptions of the use of their Twitter data, as suggested by Fiesler and Proferes (2018).

Acknowledgements: I would like to thank Dr. Sue Cranmer from Lancaster University for providing invaluable review, feedback and guidance to me while I was writing this paper. I would also like to thank Dr. Aras
Bozkurt for his work on learning ecologies in this special issue and for the opportunity to publish my paper.

\section{References}

* denotes papers included in the systematic review

Ahmed, W. (2017). Using Twitter as a data source: an overview of social media research tools (updated for 2017). Impact of Social Sciences Blog.

Ahmed, W., Bath, P., \& Demartini, G. (2017). Using Twitter as a data source: An overview of ethical, legal, and methodological challenges. Advances in Research Ethics and Integrity, 2, 79-107.

*Albertson, D. (2019, March). Twitter Activity at Recent LIS Academic Conferences. In International Conference on Information (pp. 647-653). Springer, Cham.

Austin, A. E., \& Sorcinelli, M. D. (2013). The future of faculty development: Where are we going?. New Directions for Teaching and Learning, 2013(133), 85-97.

Bali, M., \& Caines, A. (2018). A call for promoting ownership, equity, and agency in faculty development via connected learning. International Journal of Educational Technology in Higher Education, 15(1), 46.

Beach, A., Sorcinelli, M. D., Austin, A. E., \& Rivard, J. K. (2016). Introduction. In A. Beach, M.

D. Sorcinelli, A. E. Austin, \& J. K. Rivard (Eds.), Faculty development in the age of evidence: Current Practices, Future Imperatives, (pp. 1-15). Sterling: Stylus.

Bennett, S., \& Oliver, M. (2011). Talking back to theory: The missed opportunities in learning technology research. Research in Learning Technology, 19(3), 179-189.

boyd, D., \& Crawford, K. (2011, September). Six provocations for big data. In A decade in internet time: Symposium on the dynamics of the internet and society.

boyd, D. M., \& Ellison, N. B. (2007). Social network sites: Definition, history, and scholarship. Journal of computer-mediated Communication, 13(1), 210-230.

Bombaci, S. P., Farr, C. M., Gallo, H. T., Mangan, A. M., Stinson, L. T., Kaushik, M., \& Pejchar, L. (2016). Using Twitter to communicate conservation science from a professional conference. Conservation Biology, 30(1), 216-225.

Bozkurt, A., \& Hilbelink, A. (2019). Paradigm Shifts in Global Higher Education and e-learning: An ecological perspective: Special Issue: Paradigm shifts in global higher education and e-learning. eLearn, 2019(5), 1.

Bozkurt, A., Honeychurch, S., Caines, A., Maha, B. A. L. I., Koutropoulos, A., \& Cormier, D. (2016). Community tracking in a $\mathrm{CMOOC}$ and nomadic learner behavior identification on a connectivist rhizomatic learning network. Turkish Online Journal of Distance Education, 17(4).

Braun, V., \& Clarke, V. (2006). Using thematic analysis in psychology. Qualitative Research in Psychology, 3(2), 77-101. doi:https://doi.org/10.1191/1478088706qp0630a

*Budge, K., Lemon, N., \& McPherson, M. (2016). Academics who tweet: "Messy" identities in academia. Journal of Applied Research in Higher Education, 8(2), 210-221. 
Cervero, R., M. (2000). Trends and issues in continuing professional education. New Directions for Adult and Continuing Education, 86:3-12.

Chapman, A. L., \& Greenhow, C. (2019). Citizen-scholars: Social media and the changing nature of scholarship, Publications, 7(1), 1-11.

Challis M. (1999). AMEE Medical Education Guide No. 11 (revised): Portfolio-based learning and assessment in medical education. Medical Teacher, 21(4):370-386.

Conole, G., \& Alevizou, P. (2010). A literature review of the use of Web 2.0 tools in Higher Education. A report commissioned by the Higher Education Academy.

Costello, E., Donlon, E., \& Brown, M. (2019). Research ethics of Twitter for MOOCs. Online Learning (Newburyport), 23(3), 252269.

Czerniewicz, L. (2008). Fish or fowl? What is this creature called educational technology? Proceedings of the 3rd International Conference on e-Learning (ICEL). Academic Conferences Limited.

Dirckinck-Holmfeld, L. (2016). Networked learning and problem and project-based learning-how they complement each other. In Proceedings of the 10th International Conference on Networked Learning (pp. 193-199).

Donelan, H. (2016). Social media for professional development and networking opportunities in academia. Journal of Further and Higher Education, 40(5), 706-729.

Emke, M. (2019). Freelance Language Teachers' Professional Development on...and with....and Through Twitter (Doctoral dissertation, The Open University).

*Fekete, E., \& Haffner, M. (2019). Twitter and Academic Geography through the Lens of\# AAG2018. The Professional Geographer, $1-11$

*Ferguson, H., \& Wheat, K. L. (2015). Early career academic mentoring using Twitter: the case of\# ECRchat. Journal of higher education policy and management, 37(1), 3-13.

Fiesler, C., \& Proferes, N. (2018). "Participant” perceptions of Twitter research ethics. Social Media+ Society, 4(1), 2056305118763366.

Flavell, H., Harris, C., Price, C., Logan, E., \& Peterson, S. (2019). Empowering academics to be adaptive with eLearning technologies: An exploratory case study. Australasian Journal of Educational Technology, 35(1).

Frick, L., \& Kapp, C. (2009). The professional development of academics: In pursuit of scholarship. Blitzer E (ed.) 2009. Higher Education in South Africa. Stellenbosch: Sun Press

Gao, F., \& Li, L. (2019). Predicting educators' use of Twitter for professional learning and development. Education and Information Technologies, 1-17.

Gao, F., Luo, T., \& Zhang, K. (2012). Tweeting for learning: A critical analysis of research on microblogging in education published in 2008-2011. British Journal of Educational Technology, 43(5), 783-801.

Greenhow, C., Gleason, B., \& Staudt Willet, K. B. (2019). Social scholarship revisited: Changing scholarly practices in the age of social media. British Journal of Educational Technology, 50(3), 987-1004.

Greenhow, C., \& Lewin, C. (2016). Social media and education: Reconceptualizing the boundaries of formal and informal learning. Learning, media and technology, 41(1), 6-30.
${ }^{*}$ Greenhow, C., Li, J., \& Mai, M. (2019). From tweeting to meeting: Expansive professional learning and the academic conference backchannel. British Journal of Educational Technology.

Hannon, J., \& Al-Mahmood, R. (2014). The place of theory in educational research. In Rhetoric and reality: Critical perspectives on educational technology (pp. 1_6). Dunedin: Ascilite.doi:10.3102/0013189X003006003

Heffernan, T. A., \& Heffernan, A. (2019). The academic exodus: the role of institutional support in academics leaving universities and the academy. Professional Development in Education, 45(1), 102-113.

Hew, K. F., Lan, M., Tang, Y., Jia, C., \& Lo, C. K. (2019). Where is the "theory" within the field of educational technology research?. British Journal of Educational Technology, 50(3), 956-971.

Hodgson, V., \& McConnell, D. (2019). Networked learning and postdigital education. Postdigital Science and Education, (1), 43-64.

Hogue, R. J., \& Ennis-O'Connor, M. (2018). We need to talk about ethics and social media: A conversation. ETHICS FROM THE GROUND UP, 103

*Holmberg, K., \& Thelwall, M. (2014). Disciplinary differences in Twitter scholarly communication. Scientometrics, 101(2), 1027 1042.

Jones, C., \& Czerniewicz, L. (2011). Theory in learning technology. Research in Learning Technology, 19(3), 173-177.

Jordan, K., \& Weller, M. (2018a). Academics and social networking sites: Benefits, problems and tensions in professional engagement with online networking. Journal of Interactive Media in Education, 2018(1).

Jordan, K., \& Weller, M. (2018b). Communication, collaboration and identity: factor analysis of academics' perceptions of online networking. Research in Learning Technology, 26.

Kelley, P. G., Cranshaw, J., \& Sleeper, M. (2013). Conducting research on Twitter: A call for guidelines and metrics.

Kerr, S. L., \& Schmeichel, M. J. (2018). Teacher twitter chats: Gender differences in participants' contributions. Journal of Research on Technology in Education, 50(3), 241-252.

*Kimmons, R., \& Veletsianos, G. (2016). Education scholars' evolving uses of twitter as a conference backchannel and social commentary platform. British Journal of Educational Technology, 47(3), 445-464.

Kitchin, R. (2014). Big Data, new epistemologies and paradigm shifts. Big data \& society, 1(1), 2053951714528481.

*Knight, C. G., \& Kaye, L. K. (2016). ‘To tweet or not to tweet?’A comparison of academics' and students' usage of Twitter in academic contexts. Innovations in education and teaching international, 53(2), 145-155.

Krutka, D. G., \& Carpenter, J. P. (2016). Enriching professional learning networks: A framework for identification, reflection, and intention. TechTrends, 61(3), 246-252.

*Lewis, B., \& Rush, D. (2013). Experience of developing Twitterbased communities of practice in higher education. Research in Learning Technology, 21.

*Li, J., \& Greenhow, C. (2015). Scholars and social media: tweeting in the conference backchannel for professional learning. Educational Media International, 52(1), 1-14.

Looi, C. K. (2001). Enhancing learning ecology on the Internet. Journal of Computer Assisted Learning, 17(1), 13-20.

Lupton, D. (2014) 'Feeling better connected': Academics' use of social media. News \&Media Research Centre, University of 
Canberra. Retrieved from https://www.google.com/url?sa=t \& $r \mathrm{ct}=\mathrm{j} \& \mathrm{q}=\& \mathrm{esrc}=\mathrm{s} \&$ source $=$ web \& $c \mathrm{~d}=1 \& v e d=2 \mathrm{ahUKEwjKmM}$ 6uyvXhAhXItlkKHbnVCcsQFjAAegQIAxAC\&url=https $\% 3 \mathrm{~A} \% 2 \mathrm{~F}$ \%2Fwww.canberra.edu.au\%2Fabout-uc\%2Ffaculties\%2Fartsdesign $\% 2$ Fattachments $\% 2 F p d f \% 2 F n$-and-mrc\%2FFeelingBetter-Connected-report-final.pdf\&usg=AOvVaw03h0crRBHT_ iGsJhXgl--6

Mahrt, M., Weller, K., \& Peters, I. (2014). Twitter in scholarly communication. Twitter and society, 89, 399-410.

Manca, S., \& Ranieri, M. (2016). "Yes for sharing, no for teaching!”: Social Media in academic practices. The Internet and Higher Education, 29, 63-74.

Mansour, E. A. (2015). The use of Social Networking Sites (SNSs) by the faculty members of the school of library \& information science, PAAET, Kuwait. The Electronic Library, 33(3), 524-546.

Markauskaite, L., \& Reimann, P. (2014). Editorial: e-Research for education: Applied, methodological and critical perspectives. British Journal of Educational Technology, 45(3), 385-391.

*McPherson, M., Budge, K., \& Lemon, N. (2015). New practices in doing academic development: Twitter as an informal learning space. International Journal for Academic Development, 20(2), 126-136.

Meishar-Tal, H., \& Pieterse, E. (2017). Why do academics use academic social networking sites?. The international review of research in open and distributed learning, 18(1).

*Mohammadi, E., Thelwall, M., Kwasny, M., \& Holmes, K. L. (2018). Academic information on Twitter: A user survey. PloS one, 13(5), e0197265.

Moran, M., Seaman, J., \& Tinti-Kane, H. (2011). Teaching, Learning, and Sharing: How Today's Higher Education Faculty Use Social Media. Babson Survey Research Group.

Murphy, S. C. (2017). A hands-on guide to conducting psychological research on Twitter. Social Psychological and Personality Science, 8(4), 396-412.

Ödalen, J., Brommesson, D., Erlingsson, G. Ó., Schaffer, J. K., \& Fogelgren, M. (2019). Teaching university teachers to become better teachers: the effects of pedagogical training courses at six Swedish universities. Higher Education Research \& Development, 38(2), 339-353.

Oddone, K. (2019). Teachers' experience of professional learning through personal learning networks (Doctoral dissertation, Queensland University of Technology).

*O'Keeffe, M. B. (2016). Exploring higher education professionals' use of Twitter for learning. Irish Journal of Technology Enhanced Learning, 2(1), 1 - 16

*O'Keeffe, M. (2019). Academic Twitter and professional learning: myths and realities. International Journal for Academic Development, 24(1), 35-46.

Oliver, M. (2013). Learning technology: Theorising the tools we study. British Journal of Educational Technology, 44(1), 31-43.

*Parra, D., Trattner, C., Gómez, D., Hurtado, M., Wen, X., \& Lin, Y. R. (2016). Twitter in academic events: a study of temporal usage, communication, sentimental and topical patterns in 16 computer science conferences. Computer Communications, 73, 301-314.

Pataraia, N., Margaryan, A., Falconer, I., \& Littlejohn, A. (2015). How and what do academics learn through their personal networks. Journal of Further and Higher Education, 39(3), 336-357.

Pfeffer, J., Mayer, K., \& Morstatter, F. (2018). Tampering with twitter's sample api. EPJ Data Science, 7(1), 50.
*Quan-Haase, A., Martin, K., \& McCay-Peet, L. (2015). Networks of digital humanities scholars: The informational and social uses and gratifications of Twitter. Big data \& society, 2(1), 2053951715589417.

*Ramírez, H. G., \& García, R. M. G. (2015). Social Networks of Teachers in Twitter. In Information Management and Big Data (pp. 133-145). Springer, Cham.

*Reinhardt, W., Ebner, M., Beham, G., \& Costa, C. (2009). How people are using Twitter during conferences. Creativity and Innovation Competencies on the Web. Proceedings of the 5th EduMedia, 145-156.

*Ross, C. R., Maninger, R. M., LaPrairie, K. N., \& Sullivan, S. (2015). The use of Twitter in the creation of educational professional learning opportunities. Administrative Issues Journal, 5(1), 6.

*Ross, C., Terras, M., Warwick, C., \& Welsh, A. (2011). Enabled backchannel: Conference Twitter use by digital humanists. Journal of Documentation, 67(2), 214-237.

Shagrir, L. (2017). Collaborating with colleagues for the sake of academic and professional development in higher education. International Journal for Academic Development, 22(4), 331342.

*Shah, N. A. K., \& Cox, A. M. (2017). Uncovering the scholarly use of Twitter in the academia: Experiences in a British University. Malaysian Journal of Library \& Information Science, 22(3), 93-108.

*Shah, N. A. K., \& Cox, A. M. (2018, March). Analysing the Pattern of Twitter Activities Among Academics in a UK Higher Education Institution. In International Conference on Information (pp. 57-66). Springer, Cham.

*Shiffman, D. S. (2012). Twitter as a tool for conservation education and outreach: what scientific conferences can do to promote live-tweeting. Journal of Environmental Studies and Sciences, 2(3), 257-262.

Spilker, M., Prinsen, F., \& Kalz, M. (2019). Valuing technologyenhanced academic conferences for continuing professional development. A systematic literature review. Professional Development in Education, 1-18.

Staudt Willet, K. B. (2019). Revisiting How and Why Educators Use Twitter: Tweet Types and Purposes in\# Edchat. Journal of Research on Technology in Education, 1-17.

Strydom, S., \& Fourie-Malherbe, M. (2019). Pluralism as a Vehicle for Theory-building in Educational Technology Research. Theory and Method in Higher Education Research (Theory and Method in Higher Education Research, 5, 173-191.

*Stewart, B. E. (2015). In abundance: Networked participatory practices as scholarship. The International Review of Research in Open and Distributed Learning, 16(3).

Stewart, B. (2017). Twitter as method: Using Twitter as a tool to conduct research. L. Sloan, \& A. Quan-Haase, Social Media Research Methods, 251-266.

Sugimoto, C. R., Work, S., Larivière, V., \& Haustein, S. (2017). Scholarly use of social media and altmetrics: A review of the literature. Journal of the Association for Information Science and Technology, 68(9), 2037-2062.

Summers, J. A. (2017). Developing competencies in the novice nurse educator: An integrative review. Teaching and Learning in Nursing, 12(4), 263-276.

Tang, Y., \& Hew, K. F. (2017). Using Twitter for education: Beneficial or simply a waste of time?. Computers \& Education, 106, 97-118. 
Teräs, H. (2016). Collaborative online professional development for teachers in higher education. Professional development in education, 42(2), 258-275.

Trust, T., Carpenter, J. P., \& Krutka, D. G. (2017). Moving beyond silos: Professional learning networks in higher education. The Internet and Higher Education, 35, 1-11.

*Veletsianos, G. (2012). Higher education scholars' participation and practices on Twitter. Journal of Computer Assisted Learning, 28(4), 336-349.

*Veletsianos, G., Kimmons, R., Belikov, O., \& Johnson, N. (2018). Scholars' temporal participation on, temporary disengagement from, and return to Twitter. First Monday, 23(11).

Veletsianos, G., \& Kimmons, R. (2013). Scholars and faculty members' lived experiences in online social networks. The Internet and Higher Education, 16, 43-50.

Veletsianos, G. (2016). Social media in academia: Networked scholars. New York, NY: Routledge

*Veletsianos, G., \& Kimmons, R. (2016). Scholars in an increasingly open and digital world: How do education professors and students use Twitter?. The Internet and Higher Education, 30, 1-10.

Veletsianos, G., \& Shaw, A. (2018). Scholars in an increasingly open and digital world: imagined audiences and their impact on scholars' online participation. Learning, Media and Technology, 43(1), 17-30.

Veletsianos, G. (2017). Three cases of hashtags used as learning and professional development environments. TechTrends, 61(3), 284-292.

*Wen, X., Lin, Y. R., Trattner, C., \& Parra, D. (2014, September). Twitter in academic conferences: Usage, networking and participation over time. In Proceedings of the 25th ACM conference on Hypertext and social media (pp. 285-290). ACM.

Williams, R., Karousou, R., \& Mackness, J. (2011). Emergent learning and learning ecologies in Web 2.0. The International Review of Research in Open and Distributed Learning, 12(3), 39-59.

Xing, W., \& Gao, F. (2018). Exploring the relationship between online discourse and commitment in Twitter professional learning communities. Computers \& Education, 126, 388-398.

Zacher, H., Rudolph, C. W., Todorovic, T., \& Ammann, D. (2018). Academic career development: A review and research agenda. Journal of Vocational Behavior. 110, 357-373

Zou, T. X. (2018). Community-based professional development for academics: a phenomenographic study. Studies in Higher Education, 1-15.

Zwitter, A. (2014). Big data ethics. Big Data \& Society, 1(2), 1-6. 


\section{Appendices}

\section{Appendix A}

\begin{tabular}{|c|c|c|c|c|c|c|c|}
\hline ID & Authors & Type of Paper & $\begin{array}{l}\text { \# participants/ \# } \\
\text { of tweets }\end{array}$ & $\begin{array}{l}\text { Data } \\
\text { collection } \\
\text { method } \\
\end{array}$ & Duration & Discipline & Country \\
\hline A1 & $\begin{array}{l}\text { (Reinhardt, Ebner, } \\
\text { Beham \& Costa, } \\
\text { 2009) }\end{array}$ & Quantitative & $\begin{array}{l}41 \text { - } 28 \text { Male, } 13 \text { - } \\
\text { Females }\end{array}$ & Online Survey & NA & NA & NA \\
\hline A2 & $\begin{array}{l}\text { (Ross, Terras, } \\
\text { Warwick \& Welch, } \\
\text { 2011) }\end{array}$ & Mixed Methods & $\begin{array}{l}\mathrm{N} / \mathrm{A},(4,574 \\
\text { tweets, } 3 \\
\text { conferences, } 4 \\
\text { hashtags }\end{array}$ & Tweets & NA & $\begin{array}{l}\text { Digital } \\
\text { Humanities }\end{array}$ & NA \\
\hline A3 & (Veletsianos, 2012) & Qualitative & $\begin{array}{l}45-38 \text { Males, } 7 \\
\text { Females }\end{array}$ & Tweets & NA & $\begin{array}{l}\text { Social, Appied, } \\
\text { Formal Sciences, } \\
\text { Humanities }\end{array}$ & $\begin{array}{l}\text { USA, UK, Canada, } \\
\text { Spain, Portugal }\end{array}$ \\
\hline A4 & (Shiffman, 2012) & Quantitative & $\begin{array}{l}176,1,731 \\
\text { tweets }\end{array}$ & $\begin{array}{l}\text { Case Study/ } \\
\text { Tweets }\end{array}$ & 12 days & Biology & NA \\
\hline A5 & (Lewis \& Rush 2013) & Qualitative. & 1 & $\begin{array}{l}\text { Case Study/ } \\
\text { Narratives }\end{array}$ & NA & Digital Education & UK \\
\hline A6 & $\begin{array}{l}\text { (Holmberg \& } \\
\text { Thelwall, 2014) }\end{array}$ & Quantitative & $\begin{array}{l}\text { 447, approx. } \\
500 k \text { tweets }\end{array}$ & Tweets & 9 months & Various (10) & NA \\
\hline A7 & $\begin{array}{l}\text { (Wen, Lin, Trattner \& } \\
\text { Parra , 2014) }\end{array}$ & Quantitative & $\begin{array}{l}\mathrm{N} / \mathrm{A}, 109,076 \\
\text { tweets }\end{array}$ & Tweets & Over 5 years & Computer Science & NA \\
\hline A8 & $\begin{array}{l}\text { (Quan-Haase, } \\
\text { Martin \& McCay- } \\
\text { Peet, 2015) }\end{array}$ & Qualitative & $\begin{array}{l}25-14 \text { Females, } \\
11 \text { Males }\end{array}$ & $\begin{array}{l}\text { Semi- } \\
\text { structured } \\
\text { interviews }\end{array}$ & $\begin{array}{l}45-60 \\
\text { minutes }\end{array}$ & $\begin{array}{l}\text { Digital } \\
\text { Humanities }\end{array}$ & USA, UK, Ireland, \\
\hline A9 & $\begin{array}{l}\text { (Li \& Greenhow, } \\
\text { 2015) }\end{array}$ & Qualitative & 9 & $\begin{array}{l}\text { Telephone } \\
\text { interviews }\end{array}$ & 2 months & Education & NA \\
\hline A10 & $\begin{array}{l}\text { (Ferguson \& Wheat, } \\
\text { 2015) }\end{array}$ & Mixed Methods & Not stated & Tweets & 1 year & NA & NA \\
\hline A11 & $\begin{array}{l}\text { (Ross, Maninger, } \\
\text { LaPrairie \& Sullivan, } \\
\text { 2015) }\end{array}$ & Mixed Methods & $\begin{array}{l}160-105 \\
\text { Females, } 55 \\
\text { Males }\end{array}$ & Interviews & NA & Various & Mostly USA \\
\hline A12 & (Stewart, 2015) & Qualitative & $\begin{array}{l}14 \text { (13 active) } \\
4 \text { Males, } 10 \\
\text { Females }\end{array}$ & $\begin{array}{l}\text { Observation, } \\
\text { Interviews }\end{array}$ & 4 months & NA & $\begin{array}{l}\text { Canada, USA, } \\
\text { Mexico, Australia, } \\
\text { Singapore, } \\
\text { Ireland, Italy, } \\
\text { S.Africa }\end{array}$ \\
\hline A13 & $\begin{array}{l}\text { (McPherson, Budge } \\
\text { \& Lemon,2015) }\end{array}$ & Qualitative & 3 & $\begin{array}{l}\text { Narratives/ } \\
\text { Vignettes }\end{array}$ & NA & Education & Australia \\
\hline A14 & $\begin{array}{l}\text { (Kimmons \& } \\
\text { Veletsianos, 2016) }\end{array}$ & Quantitative & $\begin{array}{l}1421,360,00 \\
\text { tweets }\end{array}$ & Tweets & NA & Education & NA \\
\hline A15 & $\begin{array}{l}\text { (Budge, Lemon \& } \\
\text { McPherson, 2016) }\end{array}$ & Qualitative. & 3 & Narratives & NA & Arts & NA \\
\hline
\end{tabular}




\begin{tabular}{|c|c|c|c|c|c|c|c|}
\hline ID & Authors & Type of Paper & $\begin{array}{l}\text { \# participants/ \# } \\
\text { of tweets }\end{array}$ & $\begin{array}{l}\text { Data } \\
\text { collection } \\
\text { method } \\
\end{array}$ & Duration & Discipline & Country \\
\hline A16 & $\begin{array}{l}\text { (Knight \& Kaye, } \\
\text { 2016) }\end{array}$ & Quantitative & 26 & Online Survey & 2 months & NA & UK \\
\hline A17 & (O’Keeffe, 2016) & Qualitative & 8 & $\begin{array}{l}\text { Twitter } \\
\text { profile, } \\
\text { interviews }\end{array}$ & 1 month & NA & NA \\
\hline A18 & $\begin{array}{l}\text { (Veletsianos \& } \\
\text { Kimmons, 2016) }\end{array}$ & Quantitative & 237 & Tweets & NA & Education & NA \\
\hline A19 & (Parra et al. ,2016) & Quantitative & $\begin{array}{l}\text { NA, } 16 \\
\text { conferences, } \\
109,076 \text { tweets }\end{array}$ & Tweets & Five years & Computer Science & NA \\
\hline A20 & $\begin{array}{l}\text { (Ramirez \& Garcia, } \\
\text { 2017) }\end{array}$ & Quantitative & 43 & Tweets & 4 Months & ICT and Education & $\begin{array}{l}\text { Spain, Argentina, } \\
\text { Columbia, } \\
\text { Mexico, } \\
\text { Venezuela }\end{array}$ \\
\hline A21 & (Shah \& Cox, 2017) & Qualitative & 28 & Interviews & $\begin{array}{l}45 \text { minutes } \\
-2 \text { hours } 10 \\
\text { minutes }\end{array}$ & $\begin{array}{l}\text { Medicine, Arts, } \\
\text { Humanities, } \\
\text { Sciences, Social } \\
\text { Sciences }\end{array}$ & UK \\
\hline A22 & (O’Keeffe, 2018) & Qualitative & 7 & $\begin{array}{l}\text { Case study/ } \\
\text { Interviews }\end{array}$ & NA & Education & NA \\
\hline A23 & (Shah \& Cox, 2018) & Mixed Methods & 28 & Tweets & NA & NA & UK \\
\hline A24 & $\begin{array}{l}\text { (Veletsianos, } \\
\text { Kimmons, Belikov \& } \\
\text { Johnson, 2018) }\end{array}$ & Mixed Methods & $\begin{array}{l}3996,41 \% \\
\text { Females, 59\% } \\
\text { Males, 9,025,127 } \\
\text { tweets }\end{array}$ & Tweets & NA & NA & NA \\
\hline A25 & $\begin{array}{l}\text { (Mohammadi, } \\
\text { Thelwall, Kwasny \& } \\
\text { Holmes, 2018) }\end{array}$ & Quantitative & 1,912 & Online Survey & 2 months & NA & NA \\
\hline A26 & (Albertson, 2019) & Quantitative & $\begin{array}{l}\text { Tweets, } 3 \\
\text { conferences }\end{array}$ & Tweets & NA & LIS & NA \\
\hline A27 & $\begin{array}{l}\text { (Fekete \& Haffner, } \\
\text { 2019) }\end{array}$ & Quantitative & NA & Tweets & 4 weeks & Geography & \\
\hline A28 & $\begin{array}{l}\text { (Greenhow, Lai \& } \\
\text { Mai, 2019) }\end{array}$ & Mixed Methods & $\begin{array}{l}1095 \text { in } 2012 \\
\text { and } 4958 \text { tweets; } \\
6839 \text { in } 2016 \text { and } \\
16,588 \text { tweets }\end{array}$ & Tweets & $\begin{array}{l}2 \text { months, } 1 \\
\text { in } 2012,1 \text { in } \\
2016\end{array}$ & NA & NA \\
\hline
\end{tabular}




\section{Appendix B - Sample of Table of extracted narrative}

\begin{tabular}{|c|c|c|c|c|c|c|c|c|c|}
\hline ID & $\begin{array}{l}\text { Title of } \\
\text { Paper }\end{array}$ & Author(s) & $\begin{array}{l}\text { Type of } \\
\text { paper }\end{array}$ & $\begin{array}{l}\text { Method/ } \\
\text { Methodology }\end{array}$ & $\begin{array}{l}\text { Theory / } \\
\text { Theoretical } \\
\text { perspective }\end{array}$ & $\begin{array}{l}\text { participants' } \\
\text { demographics } \\
\text { - \#, affiliation, } \\
\text { status, sample } \\
\text { size }\end{array}$ & Discipline & $\begin{array}{l}\text { Findings - How was } \\
\text { Twitter used? }\end{array}$ & $\begin{array}{l}\text { Successful } \\
\text { Outcomes and } \\
\text { Challenges }\end{array}$ \\
\hline A1 & $\begin{array}{l}\text { How } \\
\text { People } \\
\text { are using } \\
\text { Twitter } \\
\text { during } \\
\text { Conferen- } \\
\text { ces }\end{array}$ & $\begin{array}{l}\text { Reinhardt, } \\
\text { Ebner, Beham } \\
\text { \& Costa, } \\
2009\end{array}$ & $\begin{array}{l}\text { Descriptive/ } \\
\text { Quantitative }\end{array}$ & Online Survey & $\begin{array}{l}\text { None } \\
\text { mentioned }\end{array}$ & $\begin{array}{l}5 \text { Conferences } \\
\text { with } 41 \\
\text { Participants. } 1 \\
\text { responses. } 28 \\
(68.3 \%) \text { male } \\
\text { and } 13(31.7 \%) \\
\text { female }\end{array}$ & Not Stated & $\begin{array}{l}\text { Communication, } \\
\text { sharing resources, } \\
\text { connecting to } \\
\text { diverse audiences, } \\
\text { online knowledge } \\
\text { enhancement }\end{array}$ & $\begin{array}{l}\text { Small sample } \\
\text { size. Content } \\
\text { attached to } \\
\text { tweets was } \\
\text { reported to be } \\
\text { mostly limited } \\
\text { to plain text and } \\
\text { web links }\end{array}$ \\
\hline A2 & $\begin{array}{l}\text { Enabled } \\
\text { backchan- } \\
\text { nel: con- } \\
\text { ference. } \\
\text { Twitter use } \\
\text { by digital } \\
\text { humanists }\end{array}$ & $\begin{array}{l}\text { Ross, Terras, } \\
\text { Warwick \& } \\
\text { Welch, } 2011\end{array}$ & $\begin{array}{l}\text { Mixed } \\
\text { Methods }\end{array}$ & $\begin{array}{l}4,574 \\
\text { “Tweets } \\
\text { analysed } \\
\text { using open } \\
\text { coding, text } \\
\text { analysis } \\
\text { and other } \\
\text { quantitative } \\
\text { methods }\end{array}$ & $\begin{array}{l}\text { Not } \\
\text { mentioned }\end{array}$ & Not mentioned & $\begin{array}{l}\text { Digital } \\
\text { Humanities/ } \\
\text { Digital } \\
\text { Humanists. }\end{array}$ & $\begin{array}{l}\text { Twitter as a } \\
\text { conference platform } \\
\text { enables the } \\
\text { community to expand } \\
\text { communication } \\
\text { beyond conf. } \\
\text { Actual backchannel } \\
\text { activity is a complex } \\
\text { multidimensional } \\
\text { space. Participants } \\
\text { use Twitter to } \\
\text { keep up to date. } \\
\text { Developing networks. } \\
\text { Professional } \\
\text { development. Note } \\
\text { taking/making was } \\
\text { important use of } \\
\text { backchannel/social } \\
\text { reporting... }\end{array}$ & $\begin{array}{l}\text { This group of } \\
\text { conference } \\
\text { participants } \\
\text { are a close-knit } \\
\text { group. Could be } \\
\text { intimidating to } \\
\text { newcomers. } \\
\text { Issues about } \\
\text { civility in } \\
\text { backchannel } \\
\text { raised. Small } \\
\text { groups of users } \\
\text { produce most } \\
\text { content }\end{array}$ \\
\hline A3 & $\begin{array}{l}\text { Higher } \\
\text { education } \\
\text { scholars' } \\
\text { participa- } \\
\text { tion and } \\
\text { practices } \\
\text { on Twitter }\end{array}$ & $\begin{array}{l}\text { Veletsianos, } \\
2012\end{array}$ & $\begin{array}{l}\text { Descriptive/ } \\
\text { Qualitative }\end{array}$ & $\begin{array}{l}\text { Tweets from } \\
\text { Scholars. } \\
\text { Constant } \\
\text { comparative } \\
\text { content } \\
\text { analysis - a } \\
\text { priori codes } \\
\text { avoided to } \\
\text { minimize bias } \\
\text { / limit scope } \\
\text { of analysis. } \\
\text { Intercoder } \\
\text { reliability } \\
\text { and thick } \\
\text { descriptions } \\
\text { used }\end{array}$ & $\begin{array}{l}\text { Not } \\
\text { mentioned }\end{array}$ & $\begin{array}{l}45 \text { scholars with } \\
\text { research and } \\
\text { teaching duties } \\
\text { - } 38 \text { Males, } 7 \\
\text { Females, have } \\
\text { PhD, employed } \\
\text { at HE institution. } \\
\text { Have more than } \\
2000 \text { followers } \\
100 \text { latest } \\
\text { tweets from } 45 \\
\text { participants - } \\
4500 \text { tweets; } \\
\text { location - U.S.A. } \\
\text { (32), followed by } \\
\text { Canada (6), U.K. } \\
\text { (2), Spain } \\
\text { (2), and Portugal } \\
\text { (1). }\end{array}$ & $\begin{array}{l}\text { Social } \\
\text { Sciences, } \\
\text { Applied } \\
\text { Sciences, } \\
\text { Humanities, } \\
\text { Formal } \\
\text { sciences }\end{array}$ & $\begin{array}{l}\text { (1) share info and } \\
\text { resources, (2) shared } \\
\text { information about } \\
\text { their classroom and } \\
\text { their students; (3) } \\
\text { requested assistance } \\
\text { from and offered } \\
\text { suggestions to } \\
\text { others; (4) } \\
\text { engaged in social } \\
\text { commentary; } \\
\text { (5) engaged in } \\
\text { digital identity } \\
\text { and impression } \\
\text { management; } \\
\text { (6) sought to } \\
\text { network and make } \\
\text { connections with } \\
\text { others; and (7) } \\
\text { highlighted their } \\
\text { participation in } \\
\text { online networks } \\
\text { other than Twitter }\end{array}$ & $\begin{array}{l}2000 \text { followers } \\
\text { suggest these } \\
\text { are prominent } \\
\text { scholars, } \\
\text { perhaps well } \\
\text { advanced in } \\
\text { their field and } \\
\text { influential. } \\
100 \text { latest } \\
\text { tweets may not } \\
\text { be reflective } \\
\text { of scholars' } \\
\text { normal use } \\
\text { of Twitter? } \\
\text { Some tweets } \\
\text { translated to } \\
\text { English from } \\
\text { Spanish, French } \\
\text { and Portuguese }\end{array}$ \\
\hline
\end{tabular}

